\title{
Two center experiences of Paget's disease of the breast in a sunny coastal city
}

\section{Güineşli bir sahill şehrinden iki merkezin memede Paget hastalığı deneyimleri}

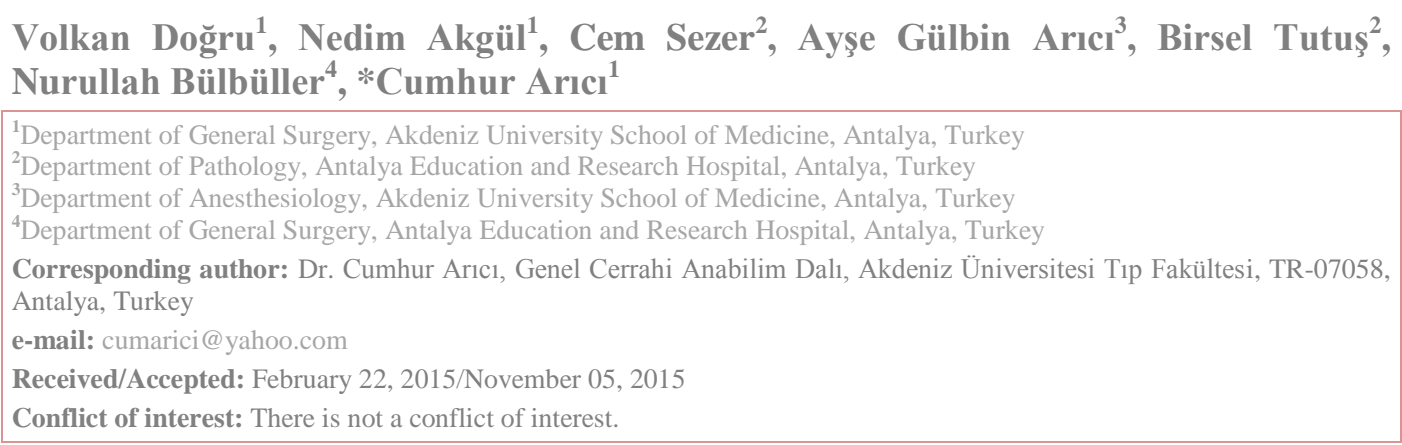

\section{SUMMARY}

Paget's disease of the breast, is a rare disease of the breast which involves nipple and areola complex. There is often an underlying in situ or invasive breast cancer. This article compares and discuss information related to Paget's disease of the breast obtained from the medical literature with the experience gained from cases followed in two seperate centers, in a southern costal city of Turkey, Antalya where there is a climate with abundant sun exposure most of the year. Sun exposure has been shown to be a modifiable risk factor for breast cancer and might play a role in the pathogenesis of Paget's disease of the breast as well. This study aims to present clinicopathologic profiles of Paget's disease patients from the city.

Keywords: Paget's disease of the breast, breast cancer, sun exposure, nipple and areola complex

\section{ÖZET}

Memenin Paget hastalığ1 meme başı ve areola kompleksini tutan memenin nadir görülen bir hastalığıdır. Siklıkla altta yatan in situ veya invaziv meme kanseri birlikteliğine rastlanır. Bu makale, memenin Paget hastalığı hakkında literatürden derlenen bilgileri yılın büyük bir döneminde havanın oldukça güneşli seyrettiği Türkiye’nin güney sahilinden bir şehirden, Antalya'dan, iki ayrı merkezde rastlanılan vakalar ile elde edinilen deneyimi kıyaslayarak tartışmayı hedeflemektedir. Güneşe maruziyet meme kanseri için müdahele edilebilen risk faktörlerinden olduğu gösterilmiştir ve memenin Paget hastalığının patogenezinde rol oynuyor olabilir. Çalışma, bu şehirdeki Paget hastalarının klinikopatolojik profillerini sunmayı amaçlamaktadır.

Anahtar sözcükler: Memenin Paget hastalığı, meme kanseri, güneşe maruziyet, meme başı ve areola kompleksi 


\section{INTRODUCTION}

Paget's disease of the breast (PDB), is one of the rare diseases of the breast which involves nipple and areola complex and often accompanied by underlying in situ or invasive breast cancer. Symptoms like slight redness, mild itching or skin peeling around the areola are early complaints of Paget's patients. These complaints are often underestimated and neglected or easily be confused with skin diseases such as dermatitis thus may be omitted from clinical consideration for malignancy. The skin changes constituting the disease usually persist, albeit with fluctuating severity. Sometimes there might be skin lesions concealed from immediate view attracting far less attention than an obscure lump in the breast. Existence of such lesions can be inferred only from a close dermatologic examination. Muttarak et al. ${ }^{1}$, in their study of 16 patients reported that $31 \%$ of patients had learned the diagnosis of $\mathrm{Pa}-$ get's disease of the breast from pathology reports after their operations. As the disease progresses more noticeable symptoms like nipple discharge, skin crusting and thickening, diffuse redness, severe itching and burning sensation, flattening or retraction of the nipple begin. Disease progression without an efficient response to dermatological treatments or presence of an accompanying suspicious mass in physical examination or radiological scanning renders inevitable to acknowledge the essential contributions of pathologic investigation. In the event of a positive skin biopsy for Paget's disease of the breast, even if there is no suspicion of malignancy on mammogram, patient should be notified that there is $85-100 \%$ likelihood of in situ or invasive breast cancer and surgery to remove the entire breast should be recommended $^{2,3}$. In the ensuing time frame of developing a well-defined treatment plan, in-person patient-doctor discussions is of great importance. Increasing awareness for breast reconstruction options after mastectomy mostly maintains a psychological, relaxing effect and well appreciated by patients.

The sun exposure is suggested in many studies to be associated with a decreased risk of breast cancer but the exact metabo- lism playing a role in this relation is not known. Although there is not any prospective controlled study to prove this hypothesis most likely due to the difficulty in quantification of the sun exposure this study selects and discuss clinical profiles of patients who have lived their lives in a southern costal city of Turkey, Antalya where there is a climate with abundant sun exposure most of the year.

\section{MATERIAL AND METHODS}

Between 2007 and 2014, twenty one patients from general surgical wards of Akdeniz University Hospital and Antalya Training and Research Hospital, followed with a diagnosis of Paget's disease of the breast were analyzed retrospectively in terms of kinds of surgery performed, pathology type, receptor positivity and axillary involvement.

\section{RESULTS}

Out of 21 patients with a mean age of 52.9 (36-75) there were 14 with modified radical mastectomy (MRM), 3 with lumpectomy, 2 with radical mastectomy and one with simple mastectomy and sentinel lymph node sampling (Figure 1).

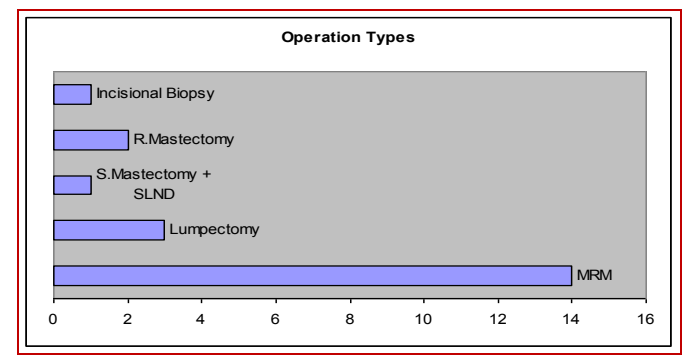

Figure 1: Types of operations performed in patients with Paget's disease of the breast. (R.Mastectomy: Radical mastectomy, S. Mastectomy: Simple mastectomy, SLND: Sentinel lymph node dissection).

Although warned repeatedly about the likelihood of in situ or invasive breast cancer one patient refused operation after skin biopsy revealing benign changes.

Three lumpectomy patients with clear margins rejected mastectomy. Invasive ductal carcinoma was detected on 17 patients and microinvasive cancer was found in 3 (Figure 2). 


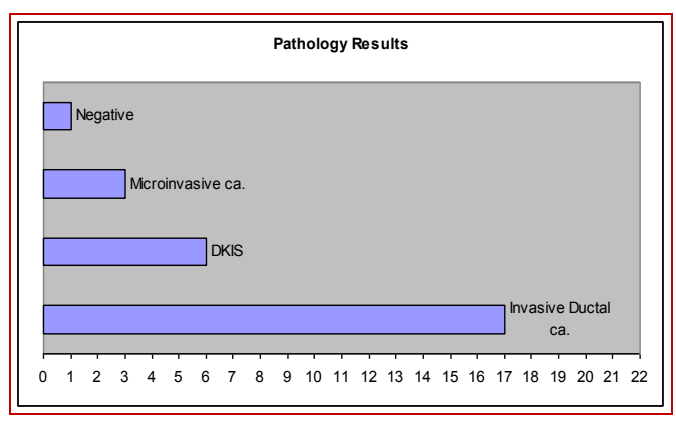

Figure 2: Pathology results of patients with Paget's disease of the breast.

(Microinvasive ca: Microinvasive carcinoma, DKIS: Ductal carcinoma in-situ, Invasive ductal ca.: Invasive ductal carcinoma). In 9 patients there was metastasis in axillary lymph nodes (Figure 3).

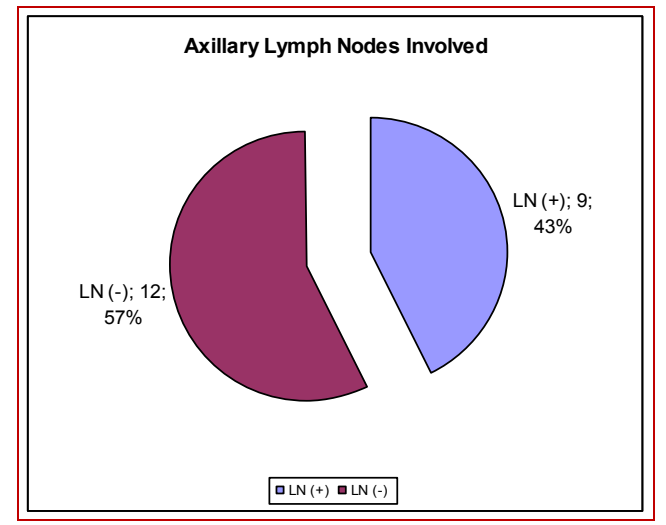

Figure 3: Axillary lymph nodes involved in patients with Paget's disease of the breast. (LN: Lymph nodes).

Estrogen-receptor was positive in 6 patients and there were 8 patients with positive progesteron receptor. HER-2 neu was positive in 16 patients (Figure 4 ).

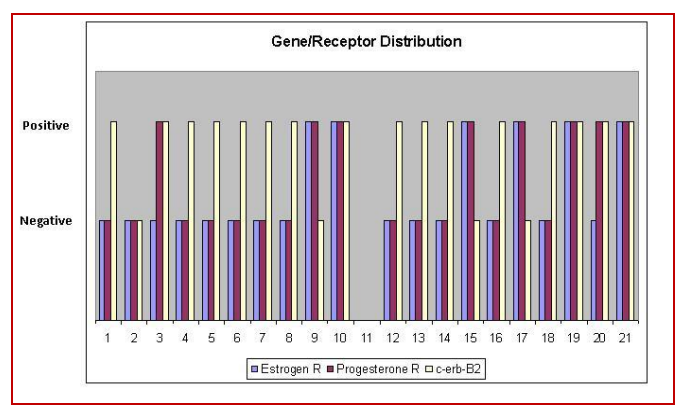

Figure 4: Gene and receptor distribution in patients with Paget's disease of the breast. (Estrogen R: Estrogen receptor, Progesterone R: Progesterone receptor).

\section{DISCUSSION}

The exact cause of Paget's disease of the breast is not yet known. According to the epidermotropic theory, one of the compel- ling theories regarding the pathogenesis of PDB, a number of cells break loose from primary breast cancer foci developing in the parenchyma of breast and migrate along the laktiferous ducts into the nipple ${ }^{4}$. Another view, known as the in situ transformation theory, suggests a spontaneous conversion of cells around the nipple into cancerous cells ${ }^{5}$. A delay in diagnosis can occur due to benign appearance. The avarege time elapsed between the onset of symptoms and the initial visit to a health care provider is 6 months ${ }^{6}$. PDB constitutes $1-3 \%$ of all breast malignancies ${ }^{7}$. There is an underlying in situ or invasive breast cancer in the vast majority of patients $^{2,3}$. Based on our experience while $80.9 \%$ of patients had invasive breast cancer, $14.3 \%$ had microinvasive breast cancer (Figure 2). The series of Kothari et al. ${ }^{3}$ comprised an all-female population of 70 patients with a median age of 56 years (2988 ). The average age of diagnosis was 52.9 (36-75) in our series which was also allfemale. Marczyk et al. ${ }^{8}$. in their immunohistochemical study of 69 patients with PDB reported that estrogen and progesterone receptor positivity are $10.1 \%$ and $2.7 \%$, respectively. Immunoreactivity with c-erbB2 was found over $80 \%$.

The sun exposure is suggested in many studies to be linked with a decreased risk of breast cancer-12. Wu et al. ${ }^{13}$ reported in their study investigating the relationship between sunlight exposure and breast density that the higher sunlight exposure is related to a lower risk of having high risk breast density pattern in premenopausal women. Sunlight exposure was assessed in 650 patients according to a questionnaire via telephone and breast density classified according to mammograms. Paget's disease of the breast includes a very restricted population of breast cancer patients and only twenty one patients who had been living their lives in a southern costal city could be gathered from a 7 year period, and quantification efforts for the sun exposure was considered ineffective. Conceivably, to our knowledge, there is no clinical report that suggests sun light making a difference in PDB patients. On the other hand, when we look at the clinicopathologic profiles of the patients in our study from 
Antalya, estrogen and progesterone receptors were positive in $28.6 \%$ and $38.1 \%$ of the patients, respectively. Immunoreactivity with c-erbB2 was $76.2 \%$.

In conclusion; in the presence of the early skin changes the possibility of PDB should always be kept in mind. Detailed pathological examination may provide a means for early diagnosis of the disease. Estrogen and progesterone hormone receptor status of PDB patients with underlying breast cancer is often negative and immunoreactivity with c-erbB2 is mostly positive; explaining why these patients have more aggresive tumors with respect to other breast cancer subgroups. Skin changes in PDB are useful clues in early diagnosis for underlying breast cancer and thereby may offer a better chance of cure. Thus, every woman above the age of 20 on their annual preventive care visit should be informed about the importance of skin changes regarding PDB and breast cancer which will be reinforcing breast health awareness in the community. Sun exposure is a modifiable risk factor for breast cancer and might play a role in the pathogenesis of PDB. Although patient number in our study is not high enough to draw a very solid conclusion, so further bigger population study is needed, relationship between sun exposure and hormone receptor positivity in PDB can be further investigated in the light of this study.

\section{REFERENCES}

1. Muttarak M, Siriya B, Kongmebhol P, Chaiwun B, Sukhamwang N. Paget's disease of the breast: clinical, imaging and pathologic Findings: A review of 16 patients. Biomed Imaging Interv J 2011; 7: 16.

2. Chen CY, Sun LM, Anderson BO. Paget disease of the breast: Changing patterns of incidence, clinical presentation, and treatment in the U.S. Cancer 2006; 107: 1448-58.

3. Kothari AS, Beechey-Newman N, Hamed H, Fentiman IS, D'Arrigo C, Hanby AM. Paget disease of the nipple: A multifocal manifestation of higher-risk disease. Cancer 2002; 95: 1-7.

4. Lagios MD, Westdahl PR, Rose
MR, Concannon S. Paget's disease of the nipple. Alternative management in cases without or with minimal extent of underlying breast carcinoma. Cancer 1984; 54: 545-51

5. Jamali FR, Ricci A Jr, Deckers PJ. Paget's disease of the nippleareola complex. Surg Clin North Am 1996; 76: 365-81.

6. Lev-Schelouch D1, Sperber F, Gat A, Klausner J, Gutman M. Paget's disease of the breast. Harefuah 2003; 142: 433-85.

7. Dixon AR, Galea MH, Ellis IO, Elston CW, Blamey RW. Paget's disease of the nipple. Br J Surg 1991; 78: 722-3.

8. Marczyk E, Kruczak A, Ambicka A, Mularz K, Harazin-Lechowska A, Moskal J, Sokołowski A, Mituś J, Ryś J. The routine immunohistochemical evaluation in Paget disease of the nipple. Pol J Pathol 2011; 62: 229-35.

9. Stoll F, Akladios CY, Mathelin C. Vitamin D and breast cancer: is there a link? Gynecol Obstet Fertil 2013; 41: 242-50.

10. Alco G, Igdem S, Dincer $M$, Ozmen V, Saglam S, Selamoglu D, Erdogan Z, Ordu C, Pilanci KN, Bozdogan A, Yenice S, Tecimer C, Demir G, Koksal G, Okkan S. Vitamin D levels in patients with breast cancer: Importance of dressing style. Asian Pac J Cancer Prev 2014; 15: 1357-62.

11. Fuhrman BJ, Freedman DM, Bhatti P, Doody MM, Fu YP, Chang SC, Linet MS, Sigurdson AJ. Sunlight, polymorphisms of vitamin D-related genes and risk of breast cancer. Anticancer Res 2013; 33: 543-51.

12. Hansen J, Lassen CF. Nested casecontrol study of night shift work and breast cancer risk among women in the Danish military. Occup Environ Med 2012; 69: 551-6.

13. Wu SH, Ho SC, So E, Lam TP, Woo J, Yuen P, Qin L, Ku S. J Sunlight exposure and breast density: a population-based study. Breast Cancer 2013; 16: 171-7. 